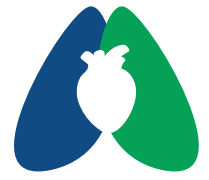

ASSOBRAFIR

CI Î N C I A

\section{Respiratory physiotherapy in COVID-19: a case report}

\author{
Fisioterapia respiratória no COVID-19: relato de caso
}

Mayron Faria Oliveira1* (1D; Carlos Alberto Lopes $^{1}$ (D); Miguel Koite Rodrigues ${ }^{1}$ (D)

\begin{abstract}
Background: the clinical aspect of COVID-19 ranges to pneumonia to critically ill cases; however, there is a lack of studies reporting respiratory physiotherapy treatment in hospitalized COVID-19 patients. Aim: we aimed to analyze the acute respiratory physiotherapy treatment in a patient with COVID-19. Methods: A symptomatic (fever 38.0 ; dry-cough; dyspnea) young patient (30 years of age) with COVID-19 received oxygen therapy and respiratory physiotherapy during hospitalization. Pulmonary function was analyzed by computed tomography (CT) and by electrical impedance tomography (EIT). Results: CT demonstrated ground-glass opacity in the right lung and EIT demonstrated an improvement in pulmonary ventilation with a reduction in the pulmonary collapse after respiratory physiotherapy; self-report symptoms (dyspnea and shortness of breath) and the oxygen therapy were reduced after respiratory physiotherapy. Conclusion: we concluded that respiratory physiotherapy, even in non-critical ill patients, could lead a better pulmonary recovery and prevent worsening the scenario in COVID-19 patients.
\end{abstract}

Keywords: COVID-19; Coronavirus; SARS-CoV-2; Physiotherapy; Intensive Care.

\section{Resumo}

Introdução: o aspecto clínico da COVID-19 varia de pneumonia a casos graves; no entanto, há uma falta de estudos relatando o tratamento de fisioterapia respiratória em pacientes com COVID-19 hospitalizados. Objetivo: nosso objetivo foi analisar o tratamento fisioterapêutico respiratório agudo em um paciente com COVID-19. Métodos: paciente jovem (30 anos de idade) sintomático (febre 38, $0^{\circ}$; tosse seca; dispneia) com COVID-19 recebeu oxigenoterapia e fisioterapia respiratória durante a internação. A função pulmonar foi analisada por tomografia computadorizada (TC) e por tomografia de impedância elétrica (TIE). Resultados: a TC demonstrou opacidade em vidro fosco no pulmão direito e a EIT demonstrou melhora da ventilação pulmonar com redução do colapso pulmonar após fisioterapia respiratória; sintomas autorreferidos (dispneia e falta de ar) e oxigenoterapia foram reduzidos após fisioterapia respiratória. Conclusão: concluímos que a fisioterapia respiratória, mesmo em pacientes não críticos, pode levar a uma melhor recuperação pulmonar e prevenir a piora do quadro em pacientes com COVID-19.

Palavras-chave: COVID-19; Coronavírus; SARS-CoV-2; Fisioterapia; Terapia Intensiva.
'Grupo de Pesquisa VO2 Care, Unidade de Fisioterapia, Hospital Vila Nova Star, São Paulo, SP, Brasil

How to cite: Oliveira MF, Lopes CA, Rodrigues MK. Respiratory physiotherapy in COVID-19: a case report. ASSOBRAFIR Ciênc. 2021;11:e42139. https://doi. org/10.47066/2177-9333.AC.2020.0010

Submitted on: November 19, 2020 Accepted on: February 10, 2021

Study carried out at: Vila Nova Star Hospital, São Paulo, SP, Brasil. Ethical approval: CAAE 30156420.8.0000.0087 da Rede D'OR de ensino e pesquisa, 3.944.457

\section{*Corresponding author:}

Mayron Faria Oliveira. E-mail: mayronfaria@ gmail.com, mayronfaria@hotmail.com
This an Open Access article published and distributed under a Creative Commons Attribution NonComercial ShareAlike License which permits unrestricted non-commercial use, distribution, and reproduction in any medium provided the original work is properly cited and is not represented as endorsing the use made of the work. Further, any new works must be made av 


\section{INTRODUCTION}

The world's population has been recently dealing with a new infectious disease, COVID-19 epidemic, which is related to high morbidity and mortality rates ${ }^{1}$. The clinical aspect of COVID-19 ranges to pneumonia to critically ill cases including clinical treatment and mechanical ventilation and, in this scenario, respiratory physiotherapy assistance is important to reduce adverse events and promote pulmonary/respiratory treatment ${ }^{2,3}$. However, there is a lack of studies reporting clinical respiratory physiotherapy treatment and outcomes regarding mild COVID-19 during hospitalization. In this line, we analysed the acute effects of respiratory physiotherapy obtained from a symptomatic COVID-19 patient during hospitalization.

\section{CASE REPORT}

The patient hospitalization followed the hospital protocol (ABG with hypoxemia, dyspnoea and self-reported symptoms with sings of using accessory respiratory muscles) with positive COVID-19 and CT confirmation. A young otherwise healthy individual (30 yrs, BMI: $26.23 \mathrm{~kg} / \mathrm{m}^{2}$ ) became ill with COVID-19 infection, which was confirmed by nasal and throat swabs, real-time RTPCR and by a computed tomography (CT) to characterize the COVID-19. The electrical impedance tomography (EIT; Enlight 1800; Timpel SA, São Paulo, Brazil) was performed before and after respiratory physiotherapy to assess, at the bedside in real time, changes in lung volume and collapsed areas. Briefly, EIT is a noninvasive, radiation-free clinical imaging tool to monitor, in real time and at the bedside, the distribution of lung ventilation. The device has small alternating electrical currents are delivered through 8-32 equally spaced electrodes applied circumferentially around the thorax. The EIT device generate up to 50 images per second with image reconstruction based on the estimation of the resistivity changes that occur across the lungs with breathing and allows the dynamic study of lung ventilation distribution. With EIT it is possible to show that some areas start to inflate after the others, reflecting both tidal recruitment and the lung improvements after interventions as respiratory physiotherapy ${ }^{4}$.

The patient was isolated during all hospital period following the world health organization's interim guidance and respiratory physiotherapy was performed according to the Vila Nova Star Hospital (São Paulo, Brazil) protocol during all hospitalization period. The performed protocol was related to diaphragmatic re-education techniques and positioning, breathing exercises with lung expansion in association with upper limbs. In addition, when the 0-10 Borg scale was less than or equal to 4, active exercises were performed. Furthermore, according to hospital protocol, oxygen weaning was considered when $\mathrm{SpO}_{2}$ is greater than or equal to $92 \%$ without respiratory failure signs.

This case report was approved by the Institutional Ethics Committee (CAE number 30156420.8.0000.0087); following resolution number 466/2012 of the National Health Council and with the 1964 Helsinki Declaration and its later amendments or comparable ethical standards. Written informed consent was obtained from the patient.

A symptomatic young patient with COVID-19 (fever 38.0 dry-cough, $\mathrm{SpO}_{2} 88 \%$, severe dyspnoea (6 points in a 0-10 Borg scale), MAP $102 \mathrm{mmHg}$, HR 98 bpm, respiratory rate (RR) of 35 and $A B G\left(p H ~ 7.42 ; \mathrm{PaO}_{2}\right.$ 56.8; $\mathrm{PaCO}_{2} 40.9 ; \mathrm{HCO}^{3}$ 26.4; $\mathrm{BE}$ 2.3; $\mathrm{SaO}_{2}$ 89.8\%; P/F ratio 189) was immediately admitted into ICU and received supplemental oxygen through a facemask ( $3 \mathrm{~L} / \mathrm{min}$ ) and given the shortness of breath and hypoxemia, respiratory physiotherapy was performed as a non-pharmacological treatment for main symptoms. Patient was given intravenous ceftriaxone, clarithromycin (orally), saline solution and painkiller; blood samples (Hb $13.1 \mathrm{~g} / \mathrm{dL}$; Hematocrit 38.8\%) demonstrated a high value of C-reactive protein (CPR $5.84 \mathrm{mg} / \mathrm{dL}$ ) with a reduced value of platelets $\left(143,000 / \mathrm{mm}^{3}\right)$ and normal leukocytes and creatinine $\left(4,730 / \mathrm{mm}^{3} ; 18 \mathrm{mg} / \mathrm{dL}\right)$, respectively.

The CT ground glass opacity was observed in the right lung with pulmonary collapse (Figure 1, panel A). The EIT (60 minutes after respiratory physiotherapy) shows a great
Panel A

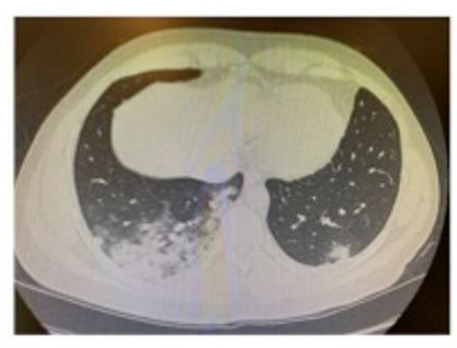

Panel B

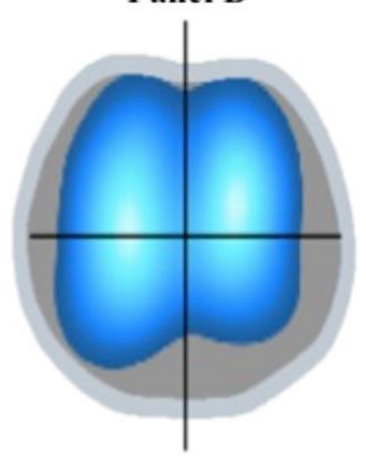

Panel C

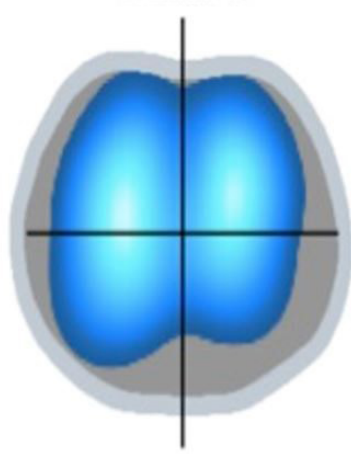

Panel D

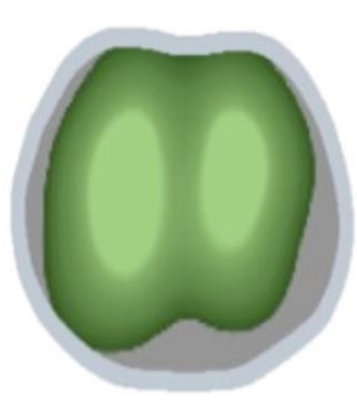

Figure 1. CT from a young patient showing a ground glass opacity and pulmonary collapse of right lung (panel A). EIT shows the improvement in pulmonary volume before (panel B) and after (panel C) acute respiratory physiotherapy. Panel D demonstrates de lung variation (delta) between before and after respiratory physiotherapy (green image demonstrated the lung improvement after respiratory physiotherapy). 
improvement in pulmonary volume in both lungs (Figure 1, panel B and C) after respiratory physiotherapy. Moreover, it is possible to note a lung volume enhancement compared to baseline measurements (lung variation (delta) between before and after respiratory physiotherapy techniques) showed in Figure 1, panel D.

In addition, there were improvements in the self-report symptoms (dyspnoea reduced 3 points), reduction on respiratory muscle accessory recruitment, RR and blood oxygenation improvement (ABG pH 7.43; $\mathrm{PaO}_{2}$ 61.6; $\mathrm{PaCO}_{2}$ 39.0; $\mathrm{HCO}_{3}$ 26.3; $\mathrm{BE} 2.1 ; \mathrm{SaO}_{2}$ 92.3\%; P/F ratio 246). Based on the all those clinical improvements after respiratory physiotherapy a reduction on oxygen supplementation was performed to nasal cannula. Furthermore, the patient had a continuous and progressive clinical improvement and was discharged from hospital without oxygen supplementation (total of 8 days in ICU and 13 days of total length of hospital stay).

\section{DISCUSSION}

Our study demonstrated, in a single patient with mild COVID-19 during hospitalization, an improvement in respiratory symptoms and in lung volume (measured through the EIT) after respiratory physiotherapy techniques. Our main findings demonstrate an enhancement in bilateral pulmonary volume with homogeneous distribution in association with an improvement in arterial blood gases, promoting an oxygen supplemental reduction.

COVID-19 infection is an acute disease and is related to $2-10 \%$ mortality rate. The disease could lead to a severe infection with alveolar damage and progressive respiratory failure ${ }^{5}$. Recently a biopsy sample demonstrates that the COVID-19 promoted a diffuse alveolar damage with cell exudate, which could worse the patient scenario in a short period of time ${ }^{6,7}$. In addition, recent report discussed that almost 30\% of COVID-19 patients could die by pneumonia and $20 \%$ by ARDS and it is well established that ICU physiotherapy in SARS patients could reduce the adverse events and improve survival ${ }^{8,9}$. In view of the high amount of pulmonary complications induced by COVID-19, the reduction of the induced lung injury being the expected benefit. In addition, the EIT in ICU could be used for a bedside analysis to evaluate the effectiveness of physiotherapy techniques. Although our study is related to a single case report our results suggest that the patient showed a significant clinical improvement after respiratory physiotherapy preventing pulmonary complications and reduced the ICU length of stay. However, further studies with large population should be addressed to confirm our data.

A study has reported that for non-critically ill patients, a close follow-up is likely to be sufficient to manage the disease, but for those who are critical ill aggressive treatment is needed ${ }^{3,10}$. However, it still difficult to characterized the disease progression since non- complicated patients could have some adverse events, and then become a critical ill. The non-pharmacological treatment with early respiratory physical therapy techniques seems to promote a beneficial effect on the clinical evaluation and in the patient's clinical outcome. We believe that the pulmonary volume improvement achieved after respiratory physiotherapy contributed to the blood oxygenation improvement and self-reported dyspnoea reduction, suggesting a non-pharmacological alternative to the drug treatment, since it could reduce pulmonary collapse areas and hospital complications odds. In addition, more than 60\% of COVID-19 had died after hospitalization at 28 days, our case repost showed a 13 days of hospital length of stay, which reinforce our hypothesis to prevent pulmonary complications with pharmacological and non-pharmacological (respiratory physiotherapy) treatment in combine. Furthermore, there are more SARS-CoV-2 diagnosed cases than ICU bedavailability, which ensures that respiratory physiotherapy must be present for all symptomatic patients, with or without mechanical ventilation ${ }^{3}$.

Despite the whole world's efforts to understand the COVID-19, many issues remain unclear; to the best of our knowledge this is the first report that measures the acute physiotherapy treatment in COVID-19 with positive result. We believe that this case report could increase the knowledge of COVID-19 treatment and the benefits of ICU treatment, since respiratory physiotherapy could prevent adverse outcomes and improve pulmonary function. However, our result should be interpreted with caution, since it is a case report and further studies with large population should be addressed, including that with mechanical ventilation.

\section{FUNDING}

Nothing to declare.

\section{CONFLICT OF INTEREST}

Nothing to declare.

\section{REFENCENCES}

1. Zou L, Ruan F, Huang M, Liang L, Huang $H$, Hong $Z$, et al. SARS-CoV-2 viral load in upper respiratory specimens of infected patients. N EngIJ Med. 2020;382(12):1177-9. http:// dx.doi.org/10.1056/NEJMc2001737. PMid:32074444.

2. Simonelli C, Paneroni M, Fokom AG, Saleri M, Speltoni I, Favero I, et al. How the COVID-19 infection tsunami revolutionized the work of respiratory physiotherapists: an experience from Northern Italy. Monaldi Arch Chest Dis. 2020;90(2). http://dx.doi.org/10.4081/monaldi.2020.1085. PMid:32431134.

3. Yang $X, Y u Y, X u J$, Shu H, Xia J, Liu H, et al. Clinical course and outcomes of critically ill patients with SARSCoV-2 pneumonia in Wuhan, China: a single-centered, retrospective, observational study. Lancet Respir Med. 
2020;8(5):475-81. http://dx.doi.org/10.1016/S22132600(20)30079-5. PMid:32105632.

4. Bachmann MC, Morais C, Bugedo G, Bruhn A, Morales $A$, Borges JB, et al. Electrical impedance tomography in acute respiratory distress syndrome. Crit Care. 2018;22(1):263. http://dx.doi.org/10.1186/s13054-0182195-6. PMid:30360753.

5. Huang C, Wang Y, LiX, Ren L, Zhao J, HuY, et al. Clinical features of patients infected with 2019 novel coronavirus in Wuhan, China. Lancet. 2020;395(10223):497-506. http://dx.doi. org/10.1016/S0140-6736(20)30183-5. PMid:31986264.

6. $\mathrm{Xu} \mathrm{XW,} \mathrm{Wu} \mathrm{XX,} \mathrm{Jiang} \mathrm{XG,} \mathrm{Xu} \mathrm{KJ,} \mathrm{Ying} \mathrm{LJ,} \mathrm{Ma} \mathrm{CL,} \mathrm{et} \mathrm{al.} \mathrm{Clinical}$ findings in a group of patients infected with the 2019 novel coronavirus (SARS-Cov-2) outside of Wuhan, China: retrospective case series. BMJ. 2020;368:m606. http://dx.doi. org/10.1136/bmj.m606. PMid:32075786.

7. Xu Z, Shi L, Wang Y, Zhang J, Huang L, Zhang C, et al. Pathological findings of COVID-19 associated with acute respiratory distress syndrome. Lancet Respir Med. 2020;8(4):420-2. http://dx.doi.org/10.1016/S22132600(20)30076-X. PMid:32085846.

8. Amato MB, Meade MO, Slutsky AS, Brochard L, Costa EL, Schoenfeld DA, et al. Driving pressure and survival in the acute respiratory distress syndrome. N Engl J Med. 2015;372(8):747-55. http://dx.doi.org/10.1056/ NEJMsa1410639. PMid:25693014.

9. Lai CC, Shih TP, Ko WC, Tang HJ, Hsueh PR. Severe acute respiratory syndrome coronavirus 2 (SARS-CoV-2) and coronavirus disease-2019 (COVID-19): the epidemic and the challenges. Int J Antimicrob Agents. 2020;55(3):105924. http://dx.doi.org/10.1016/j.ijantimicag.2020.105924. PMid:32081636.

10. Zhu N, Zhang D, Wang W, Li X, Yang B, Song J, et al. A novel coronavirus from patients with pneumonia in China, 2019. N Engl J Med. 2020;382(8):727-33. http://dx.doi.org/10.1056/ NEJMoa2001017. PMid:31978945. 